\title{
Pääkirjoitus
}

\section{Tässä ajassa - Prologin ensimmäinen vuosikymmen}

Ensimmäinen Prologi - puheviestinnän vuosikirja ilmestyi joulukuussa 2005. Nyt ilmestyy kymmenes Prologi. Tänä vuonna on myös Prologia julkaisevan Prologoksen 25-vuotisjuhlavuosi. Täydet vuosikymmenet tuntuvat aina hetkeksi pysäyttävän ihmettelemään aikaa ja ajan kulkua, katsomaan taakse- ja eteenpäin. Aika on merkillinen asia. Se on nopea, kun ajattelemme sen kulkua: kuinka nopeasti aika on mennytkään! Samalla vuodet ovat pitkiä: siitähän on jo niin kauan!

Tieteen aika on hidasta aikaa. Ymmärryksen luomista, asioihin paneutumista ja perehtymistä ei voi kiirehtiä. Kun tarkastelee esimerkiksi puheviestinnän teorioiden kehittelyä huomaa, että ensimmäisistä avauksista voi olla kenties kaksi- tai kolmekymmentäkin vuotta ennen kuin teoria saa muotonsa. Esimerkiksi relationaalisen dialektiikan tai rakenteistumisen teorian kehittäminen on alkanut 1980-luvulla. Nyt ne ovat puheviestinnän tieteenalan teoreettista ydintä. Niihin nähden Prologi on vielä hyvin nuori. Kymmenen vuosikirjan tarkasteleminen ei siten vielä mahdollistakaan kehityksen suunnanmuutosten tai trendien tunnistamista. Se ei salli myöskään aavistella sitä, mitkä tämän hetken tutkimuksen teemoista ovat ytimessä kymmenen tai kahdenkymmenen vuoden kuluttua. Kymmenen vuosikirjaa mahdollistaa kuitenkin jo jonkinlaisen poikkileikkauksen siitä sadosta, jota Prologi on kymmenen vuoden aikana tuottanut.

Kymmenessä ensimmäisessä Prologissa, tämä Prologi mukaan lukien, on julkaistu 27 artikkelia, kuusi puheenvuoroa, kaksi tutkimusselostetta, kaksi esitelmää, neljä kirja-arvostelua ja 14 lectio praecursoriaa. Artikkeleista 15 on tyypiltään katsauksia. Näistä kolme on systemaattisia kirjallisuuskatsauksia, loput ovat joko narratiivisia katsauksia tai teoreettisia ja käsitteellisiä pohdintoja. Otsikoissa toistuvatkin ilmaukset "näkökulma", "lähtökohta" ja "katsaus". Katsauksia on tehty niin tutkimusmenetelmiin kuin puheviestinnän ilmiöihinkin, kuten vuorovaikutustaitoihin.

Teoreettiseen tarkasteluun Prologeissa julkaistuissa teksteissä on nostettu esimerkiksi vuorovaikutusosaaminen eri konteksteissaan sekä erilaiset vuorovaikutussuhteet, niin yksityiset kuin ammatillisetkin. Teorioista 
pohdinnan kohteena ovat olleet esimerkiksi relationaalinen dialektiikka, strukturaatioteoria ja funktionaalinen teoria. Tutkimusmenetelmistä on tarkasteltu ryhmän vuorovaikutuksen analyysimenetelmiä, viestinnän etnografiaa ja haastattelua. Ominaista Prologin alkutaipaleelle näyttää olleen moninaisten näkökulmien etsiminen sekä erinäisten vuorovaikutusilmiöiden, teorioiden ja menetelmien pohtiminen.

Prologissa julkaistuista artikkeleista kaksitoista on empiirisiä. Empiirisistä tutkimuksista suurin osa on otteeltaan laadullisia ja aineistot ovat autenttisia. Meidän onkin tutkijoina syytä olla iloisia pääsystämme esimerkiksi oppilaitoksiin, sairaaloihin ja yrityksiin. Empiirisistä artikkeleista ei voi tunnistaa temaattista painopistettä, vaan niissä on käsitelty useita eri aiheita. Nämä ovat siviilioikeudellinen retoriikka, maallikkosaarnaajan retoriikka, parisuhteen kriteerit ja normit, hoitosuhteen vuorovaikutus, huonojen uutisten kertominen, lääketieteen opiskelijoiden vuorovaikutuskoulutus, alakohtainen vuorovaikutuskoulutus, kiusaaminen, kuunteleminen keskustelussa, kollaboratiivinen vuorovaikutus, jaettu johtajuus ja vuorovaikutuksen merkitys opettajan asiantuntijuudessa.

Prologissa esitelty empiirinen tutkimus on ilmiökeskeistä ja teemoiltaan varsin moninaista. Artikkeleita yhdistäneekin lähinnä se, että tutkimuksissa on tarkasteltu hyvin ajankohtaisia teemoja. Artikkelien aiheet kertovat omaa tarinaansa paitsi siitä, mihin tutkijan kiinnostus kohdistuu, myös siitä, mikä mielletään yhteiskunnallisesti tai kulttuurisesti merkittäväksi teemaksi kunakin ajankohtana. Kun tarkastelee artikkeleita kokonaisuudessaan yhdessä puheenvuorojen ja tutkimusselosteiden kanssa, voi todeta, että toistaiseksi vuorovaikutusosaaminen ja puheviestinnän opettaminen ovat olleet teemoista vahvimmin esillä.

Jos Prologin alkutaipaleelle on ollut ominaista näkökulmien etsiminen ja löytäminen, luonteva tie eteenpäin voisi olla jatkossa empiirinen. Toistaiseksi Prologissa on nähty niukasti teorialähtöistä, teoriaa testaavia, kyseenalaistavia tai kehittäviä artikkeleja. Tilaa olisi myös kvantitatiiviselle ja monimetodiselle tutkimukselle sekä rohkealle kokeilevalle otteelle niin aineiston keruun ja valinnan kuin analyysimenetelmienkin suhteen. Nähtäväksi jää, millaiseksi Prologin seuraava vuosikymmen osoittautuu.

Aika on paitsi koettua myös historiallista aikaa. Prologi on syntynyt aikana, jolloin yliopistossa ja tiedemaailmassa on koettu suuria muutoksia. Julkaisemisen merkitystä korostetaan ja ranking-ajattelu on tullut vahvasti myös suomalaiseen tiedeyhteisöön Julkaisufoorumi-luokittelun myötä. Prologi - puheviestinnän vuosikirja on ainoa suomenkielinen tieteellinen julkaisu, joka keskittyy julkaisemaan puheviestintätieteellistä tutkimusta ja ottaa kantaa ajankohtaisiin puheviestinnän teemoihin. Se on mukana 
Julkaisufoorumin tasoluokituksessa. Prologin tärkeän aseman säilyttämisen ja edelleen kehittymisen edellytyksenä on, että puheviestinnän tutkijat tarjoavat julkaistavaksi korkeatasoisia artikkeleita nimenomaan Prologissa. Toinen tärkeä resurssi Prologille on lähitieteistä ponnistava vuorovaikutuksen tutkimus, joka paitsi tarjoaa kiinnostavaa tutkimustietoa myös rakentaa ja rikastaa vuorovaikutuksen tutkimusta. Toimituskunta on ilahtunut siitä, että muutkin kuin puheviestinnän tutkijat ovat löytäneet julkaisumme. Toivomme, että Prologiin tulee tulevaisuudessakin artikkelitarjouksia lähitieteiden aloilta.

Tänä vuonna Prologin toimituskunta otti vastaan abstraktit kahdeksasta artikkeliehdotuksesta, jotka kaikki katsottiin sopiviksi puheviestinnän vuosikirjaan. Näistä käsikirjoituksiksi valmistui viisi. Toimituskunta hyväksyi referee-kierrokselle kolme käsikirjoitusta, joista julkaistavaksi päätyi yksi. Tässä Prologissa julkaistavassa artikkelissa Sanna Vehviläinen tarkastelee vuorovaikutusta ohjaustilanteessa keskusteluanalyysin näkökulmasta. Artikkelissaan Vehviläinen erittelee kiinnostavasti ohjaamisen ja neuvomisen käsitteitä ja rakentaa ymmärrystä siitä, millaista on esimerkiksi opinnäytetöiden ohjaaminen. Artikkelista on varmasti iloa niin käytännön toimijoille kuin puheviestinnän tutkijoille.

Toukokuussa toimituskunta julkaisi tavanomaisen kirjoituspyynnön lisäksi myös puheenvuoropyynnön. Pyynnöllä haluttiin korostaa Prologin asemaa myös keskustelufoorumina. Haku tuotti kolme julkaistavaa tekstiä: yhden tutkimusnäkökulman ja kaksi puheenvuoroa. Omassa tekstissään Maija Gerlander, Teija Lukkari ja Tarja Kettunen avaavat kiinnostavan tutkimusnäkökulman, jossa he pohtivat, kuinka pitkäaikaissairaan ympärille kehittyy vuorovaikutussuhteiden verkosto ja miten potilas itse pystyy vaikuttamaan hoitoonsa. Näkökulmassaan he luonnostelevat niitä erittäin tärkeitä kysymyksiä, joita pitkäaikaissairas kohtaa ja joihin puheviestinnän tutkijoiden soisi tarttuvan. Elina Antikaisen puheenvuoron keskiössä ovat puheviestintä ja kuntatyö. Antikainen esittelee, miten puheviestinnän asiantuntijuus voi näyttäytyä ja kuinka sitä voi hyödyntää kuntasektorilla. Minna Kaihovirta-Rapo puolestaan valottaa puheenvuorossaan puheviestinnän oppisisältöjen kehitystä ammattikorkeakouluissa. Esimerkkitapauksena toimii Metropolia ammattikorkeakoulun liiketalouden alan opetus.

Tätä Prologia on toimitettu Prologoksen 25-vuotisjuhlavuonna. Toimituskunnalla oli ilo pyytää tähän julkaisuun Maarit Valoa muistelemaan Prologos ry:n perustamista. Hänen historiakatsauksensa kertoo hauskalla ja lämpimällä tavalla yhdistyksen alkutaipaleesta. Tieteellisen julkaisun tarpeellisuutta on pohdittu jo tuolloin: kuinka kauan siitä onkaan, kuinka 
nopeasti vuodet ovat menneet!

Puheviestinnän vuosikirja kokoaa aina myös puheviestinnän väitöskirjojen sadon. Tänä vuonna puheviestinnästä valmistui kolme väitöskirjaa. Vilja Laaksonen tarkasteli väitöksessään esikouluikäisten vuorovaikutussuhteiden kehittymistä ja kiusaamisen yhteyttä niihin. Anne Laajalahti tutki väitöskirjassaan tutkijoiden vuorovaikutusosaamisen informaalia oppimista. Riitta Vanhatalon väitöskirjan käsitteli vuorovaikutuksen yhteyksiä verkoston rakenteeseen, toimintaan ja jäsenten toimijuuden kokemuksiin. Heidän kaikkien lectio praecursoriat julkaistaan tässä Prologissa.

Prologin ensimmäinen toimituskunta kirjoitti marraskuussa 2005: "Prologi on nyt olemassa. Löytäköön se paikkansa tieteellisessä keskustelussa yleensä ja puheviestintätieteen keskustelussa erityisesti." Kymmenen ensimmäistä vuosikirjaa ovat täyttäneet tavoitteet kelpo tavalla, vaikka matka on vielä lyhyt tieteen ajassa. Vakiinnuttamisen eteen työtä ovat tehneet monet: kirjoittajat, arvioijat ja toimituskunnat. Toimituskunta haluaa lämpimästi kiittää niitä kaikkia kirjoittajia, jotka ovat tarjonneet käsikirjoituksiaan tämän vuoden Prologiin. Tässä numerossa julkaistaan myös arvioijat, jotka ovat arvioineet käsikirjoituksia kahden viime vuoden aikana. Toimituskunta haluaa esittää heille suuren kiitoksen korkeatasoisista ja tarkoista vertaisarvioista. Arvioijan panos on tieteelliselle julkaisulle korvaamaton, he ovat paljon vartijoina.

Prologi jatkaa tästä luottavaisesti ja uusin ilmein graafikko Ina Majaniemen suunnittelemissa kansissa. Meidän aikamme Prologin toimituskuntana on nyt lopussa. On ollut ilo toimittaa Prologia ja päästä eturintamassa näkemään, millaisia tutkimusaiheita tämä aika puheviestinnän saralla tuottaa. Toivomme, että lukukokemuksesi on yhtä antoisa kuin julkaisemisprosessit näiden kahden vuoden aikana ovat olleet.

\section{Joulukuussa 2014}

Leena Mikkola

Sanna Herkama

Jonna Koponen

Salme Korkala 